\title{
DETERMINANTS OF MATE SELECTION CHOICE AMONG UNIVERSITY STUDENTS IN SOUTH- SOUTH ZONE OF NIGERIA.
}

\author{
MALIKI, Agnes Ebi PhD \\ Educational Foundations Department \\ Niger Delta University \\ P. M. B. 071, Wilberforce Island \\ 560001 \\ Bayelsa State, Nigeria. \\ email: agnesmaliki@yahoo.com
}

\begin{abstract}
This study sought to identify factors that determine mate selection choice among university students in south-south zone of Nigeria. The study was a descriptive survey. The sample was made up of 1420 randomly selected undergraduates in south-south zone of Nigeria. They consisted of 907 male students and 512 female students, within the age brackets of $16-46$ years $(M=38.89, S D=7.72)$. The main finding of the study indicated that students consider character as the most important factor in their mate selection choice. Implications for counselling were given.
\end{abstract}

Key Words: - Mate Selection, Character, Financial Standing, Educational Qualification, Fertility

\section{Introduction}

Selecting a mate is one of the most important decisions people make during their lifetime. Mate selection is a process through a series of steps. Bee (1994) suggests that when an individual meets someone new, the individual applies three filters, in the order listed:

a. External characteristics: Does this person match you in quality of appearance, apparent social class or manners?

b. Attitudes and beliefs: Is there a match with your ideas in basic area, such as sex, religion, or politics?

c. Role fit: Does this person's idea about relationships match your own? Do you have similar ideas about appropriate sex roles? Are you compatible sexually? For example, if one partner is eager for a high level of personal self-disclosure and the other is reticent about revealing his feelings, a poor match would exist on this filter. 
Mate selection sets the tone for the early adult lifestyle. It determines one's daily routine, including the time one wakes up, one's daily activities, expenditures of physical and mental energy; and conditions for both immediate and long-term rewards. Mate selection confers social status and provides varying opportunities for advancement. It also represents a direct or indirect expression of one's value system (Newman and Newman, 1995).

One of the major tasks of young people, particularly university students is to achieve a state of identity. Erikson (1987) referred to identity as a state towards which one strives if one were in a state of identity, the various aspects of one's self-image would be in agreement with other, they would be identical, and ideally a person in the state of identity has no internal conflicts whatsoever. Youngsters, particularly university students, should develop intimacy with others at this stage; intimacy here is more than sexual intimacy, it is about the essential ability to relate one's deepest hopes and fears to another person, and to accept in turn another person's need for intimacy. Each individual is entirely alone in the sense that no one else can ever experience life exactly the way another does. Only if one becomes intimate with another is one able to understand and have confidence in oneself. During this time of life, peoples' identity may be fulfilled through the living validation of the person with whom one has dared to be intimate.

Youngsters in the universities may not have a firm sense of identity; they are in the process of identity seeking and may experience identity crisis. Identity confusion causes self-doubt. Youngsters make choices hastily and come to regret them. In the process of mate selection by university students various qualities attract an individual to a partner. As the relationship develops and progresses they come to realize that those qualities that formed the basis of attraction are not what they desire, resulting to a break up of the relationship.

The phenomenon creates emotional instability among undergraduates characterized by inability to concentrate on their academic pursuit which is their primary reason for attending university; they lack confidence, they are confused and they develop low self-esteem and negative self-concept. In spite of these problems university students still engage in mate selection.

It is against this background that this study sought to investigate factors that university students consider in mate selection. To guide this study therefore this question was raised - what factors are important to university students in mate selection choice? 


\section{Literature Review}

Relevant literature was reviewed; they include:
a. Educational background
b. Parental influence
c. Religion
d. Occupation.
e.

Educational background: O'Neil (2006) explained that education is an important factor in marriage partner choice in many societies. Buss and Schmitt (1993) posited that in marriage partner choice surveys women consistently express a preference for marriage partners who are of high educational background and of the same educational qualification as themselves. Also Kalmijn (2001) revealed that college graduates prefer to marry college graduates like themselves. However, female graduates also like to marry men that are educationally advanced than them. Corroborating Kalmijin (2001), Torr (2005) in his study of undergraduates' mate choice indicated that they prefer college graduates with good earning capacity.

Similarly Gage and Hancock (2002) posited that undergraduates prefer partners of similar educational qualification and background. A study conducted by Todosijievic, Ljubinkovic and Arancic (2003) revealed that respondents prefer potential partners that are educated and those with interesting professions.

Koehler (2005) predicted that female undergraduates may have a stronger preference for partners who are college graduates to non college graduates while male undergraduates indicated that it is not too important that their partners should be college graduates.

Parental influence: Historically, parents play a major role in choosing marriage partners for their children and the custom continues in the world's developing countries today. Parental influence is greatest when the parents have a large stake in which their child marries. Traditionally, marriage has been regarded as an alliance between two families, rather than just between the two individuals. Aristocratic families could enhance their wealth or acquire royal titles through a child's marriage. The most extreme form of parental influence is an arranged marriage in which the bride and groom have no say at all. For instance, in traditional Chinese practice, the bride and groom meet for the first time on their wedding day. In some upper-caste Hindu marriages, children are betrothed at a very young age and have no choice in the decision. In a less extreme form of arranged marriage, parents may do the match making, 
but the young people can veto the choice. Some small cultures scattered around the world have what social scientists call preferential marriage. In this system, the bride or groom is supposed to marry a particular kind of person for example, a cousin on the mother's or father's side of the family (Encarta, 2006).

In the traditional Yoruba society in Nigeria, most marriages are arranged by the parents on both sides (Bolaji, 1984). Basically, two forms of arranged marriages were common among the Yoruba's. One was the betrothal of a girl before she was born and the second, chosen by the families of the young ones concerned. The third category of marriage partner selection now prevalent among the Yoruba's is the one in which individuals concerned personally chose their own partners.

This may not be unconnected with the increased pace of modernization whereby emphasis is shifting from extended family ties, which formally existed in most of the rural areas (Orubuloye, 1987). Ogunjuyigbe and Adeyemi (2003) revealed in their study that most Yoruba men would prefer arranged marriages for their children for security purpose. This is to ensure a peaceful, successful and comfortable married life for their children.

Religion: Levi-Strauss (2006) posited that people are so particular about the demographic characteristics of their prospective spouses. College students surveyed indicated that they will not marry from another religious group that is not theirs but from the same religious group.

Occupation: In mate choice surveys women consistently express a preference for partners who have high status profession (Buss and Schmitt, 1993). Women place high value on men who posses a promising career orientation, industriousness and ambition. Women are significantly more likely to discontinue relationships with males who become unemployed, lack career motivation or show laziness (Betzig, 1989).

Townsend and Levy (1990) looked at the effects of occupation status as embodied by clothing and attractiveness on female willingness to engage in romantic relationships. Male targets were pre-rated for physical attraction and divided into two categories: handsome and homely. The targets were one of these three costumes:

Blazer, shirt, designer tie, and conspicuous Rolex watch. They were described as being doctors (high status). 
Plain white shirt: They were described as being teachers (medium status).

Uniform of a Burger king employee: They were described as being trainee waiters (low status).

Females stated their willingness to engage in relationships with the men at six levels of romantic involvement, the high status males were preferred over the low status males' at all six levels and status were more important than attractiveness. Women who are high status themselves also prefer males of high status, preferably of even higher status than themselves.

Similarly, in a survey of medical students, Townscend (2003) reported that the females become more selective in their criteria in entering a relationship, while the males were convinced that their increasing status would enable them to engage in a relationship.

\section{Methods}

\section{Research design:}

This is a survey study that made use of the descriptive survey design.

\section{Participations:}

Participants in the study were 1,420 undergraduates from seven universities randomly selected from eleven universities in south-south zone of Nigeria. The universities were University of Uyo, Akwa-Ibom State, Niger Delta University, Bayelsa State, University of Calabar, CrossRivers State, Delta State University, Delta State, Ambrose Alli University, Edo State, University of Port-Harcourt, Rivers State and Igbinedion University, Edo State. The respondents consisted of 907 male students and 512 female students within the age brackets of 16 years and 46 years, with a mean of 38.89 and standard deviation of 7.72 .

\section{Measures:}

Data collection was done through the aid of a questionnaire containing two sections. Section A tapped personal data while section B elicited information on characteristics people most consider in their mate selection containing 15 items in form of a check list with a reliability coefficient of 0.88 .

a. Procedures: The questionnaires were administered and collected in each of the universities with the help of lecturers in the different universities.

b. Statistics: Simple percentage was used to analyze the data. 


\section{Result}

Table 1. Distribution of undergraduates in terms of factors considered important in mate choice.

\begin{tabular}{|l|c|c|c|c|c|c|}
\hline \multirow{2}{*}{\multicolumn{1}{|c|}{ Factors }} & \multicolumn{6}{|c|}{ Responses } \\
\cline { 2 - 7 } & \multicolumn{2}{|c|}{ Not important } & \multicolumn{2}{c|}{ Important } & \multicolumn{2}{c|}{ Total } \\
\cline { 2 - 7 } Fespondents & $\%$ & Respondents & $\%$ & Respondents & $\%$ \\
standing & 467 & 33 & 951 & 67 & & \\
Character & 28 & 2.0 & 1392 & 98 & & \\
Educational & 137 & 9.7 & 1283 & 90.3 & & \\
qualification & & & & & \\
Body structure & 396 & 27.8 & 1024 & 72.2 & & \\
Dentition & 443 & 31.2 & 977 & 68.3 & & \\
Fertility & 82 & 5.7 & 1338 & 94.3 & & \\
Religion & 147 & 10.4 & 1273 & 89.6 & \multirow{2}{*}{1420} & \\
Ethnicity / state & 784 & 55.2 & 63.6 & 44.8 & & \\
of origin & 856 & 60.2 & 56.4 & 39.8 & & \\
Complexion & 146 & 10.3 & 1274 & 89.7 & & \\
Intelligence & 35 & 51.8 & 68.5 & 48.2 & & \\
Weight & 584 & 41.1 & 836 & 58.9 & & \\
Age similarity & 400 & 28.2 & 1020 & 71.8 & & \\
Profession & 242 & 17.0 & 1178 & 83.0 & & \\
Physical health & 505 & 35.6 & 915 & 64.4 & & \\
Height & & & & & & \\
\hline
\end{tabular}

The result showed that 98 per cent of the respondents indicated that character is the most important factor, followed by fertility with 94.3 per cent, 90.3 per cent indicated educational qualification, 89.7 percent indicated intelligence, 89.6 per cent indicated religion closely followed by physical health with 83 percent, followed by body structure with 72.2 percent, 71.8 percent indicated profession, 68.8 per cent dentition closely followed by financial standing with 67 per cent, also followed by height with 48.2 per cent indicated with 64.4 percent, 58.9 percent indicated age similarity, followed by weight with 48.2 per cent, state of origin with 44.8 percent and complexion with 39.8 per cent.

\section{Discussion}

The finding revealed the following: character was the most important factor, closely followed by fertility, educational qualification, intelligence, 
religion, physical health, body structure, profession, dentition, financial standing, height, age similarity, weight, state of origin and complexion in that order.

This revelation is not too surprising in that there is the belief that someone with good character will be a better marriage partner than someone without good character but physically attractive. Someone with good character will easily be accepted as a daughter or son-in-law by parents, siblings, friends and significant others. Also someone with good character can easily adjust to any situation since individuals are not from the same background. This study is supported by the study of Canning (2005) which revealed that emotional characteristics, personality traits and supportiveness which are good character traits are qualities that out weigh more notable characteristics such as physical attractiveness.

Fertility ranked second. This is not surprising in that the essence of marriage is for procreation. In the African setting, a marriage without a child or children is not considered to be a successful marriage and this can result into separation or divorce. This is supported by the study of Cere (2001) which posited that people seek marriage partners who show sign of reproductive viability.

Educational qualification is also considered as an important factor in marriage partner choice. This is so because respondents are all undergraduates and they will necessarily want to marry someone with good educational qualification like themselves. Observations have shown that graduates who marry partners of lower educational qualification or no education at all find it difficult to introduce their spouses in public when they go out with them and in most cases they do not attend public functions together. This could thus result into problem in the marriage. This is supported by the studies carried out by Kalmijin (2001) and LeviStrauss (2006). They revealed that college graduates prefer to marry collage graduates like themselves.

Religion is another factor that is considered important, in that it is important that individuals who desire to marry should have the same religious belief since differences in religious belief may be a disruptive force in their marriage life, while religion could be a binding force to hold marriage together for those with the same religious belief. This fact is supported by the study of Levi-Strauss (2006) that found that people are so particular about the demographic characteristic of their prospective spouses. College students surveyed indicated that they will not marry from another religious group that is not theirs but from the same religious group. 
Age similarity is another factor considered important by undergraduates; this is so because persons born within the same age range will have the same formative experience than those born several years apart. This study is supported by the study of Glenn (2000) which revealed that the desire for similarity in age becomes greater in modern societies because intimacy and companionship are much more salient goals in relationships in modern than in most traditional societies. Glenn explained further that as social and cultural changes have become more rapid in modern societies, the formative experiences of persons born only few years apart have become substantially different, and thus partners in age discrepant relationships tend to be dissimilar because of age cohort based influence as well as the developmental stage influence. This study, is in contrast with of those of Nzidee (2001), Eisenam (2002), Mamasan (2005), Beck and Powell (2005), and Denisuik (2005) - they observed that traditional wisdom and some past research hold that females will prefer older males while males will prefer younger females.

\section{Implications for Counselling}

This research study investigated and identified the factors that university undergraduates in south-south zone of Nigeria consider as important in selecting a mate. The findings of this study have been found to have counselling implication for undergraduates.

First, counsellors are to create awareness among undergraduates that the responsibility for the selection of a mate rests with the two people who are considering one another and that only the two persons directly involved will have to live daily with the consequence of this choice and only they are in a position to make a fully informed decision about the rightness of their relationship. This can be carried out through individual and group counselling.

Counsellors should educate and encourage undergraduates in their mate selection to be cautious because marrying as a teenager could be the highest risk factor for divorce than people who marry when they are in their twenties or older. Another implication is that counsellors should counsel undergraduates that if either partner has any concern about the behaviour of the other, they should not expect that this concern would simply dissolve over time.

Counsellors should also assist undergraduates to realise that they could consider the advice of friends, family members, or well-meaning acquaintance. One of the problems of mate selection by undergraduates is that of haste; counsellors should be prepared to help undergraduates in 
their choice of mates through organizing of conferences, symposia, seminars, and workshops on preference in mate choice.

\section{References}

Bee, H. (1994). Life Span Development: New York: Harper Collins College.

Beck, C. \& Powell, L. (2005). Mate Selection and age: What Females really want. Journal of Evolutionary Ecology_Research, 84 (2), 96-113.

Betzig, L. (1989). Causes of Conjugal Dissolution. Current Anthropology, 30, 654-676.

Bolaji, S. I. (1984). Yoruba Living Heritage. Ibadan: Omoleye Publishing Company.

Buss, D. M. \& Schmitt, D. P. (1993). Sexual Strategies Theory: An Evolutionary Perspective on Human Mating. Psychological Inventory, 6, 1-30.

Canning, M. P. (2005). Personality and Physical appearance as predictors of Mate selection in females.

Cere, D. (2001). Courtship today: The view from academia. Achieved Issue. http//A;/ courtship today the view from academic. Htm. Access date 12/12/2007.

Esienam,J.B. (2002). Human mating strategies and sexual preferences. http://wiki.cotch.net/index.php/human_mating_strategies_and_ sexual_preferences. Date of access 10/12/2007.

Encarta (2006). Marriage. http://encarta.msn.com/refpages/refarticle. aspx?refid $=761574825$. Date of access 10/12/2007.

Denisiuk, J. S. (2005). Evolutionary Versus Social Structural explanations for sex differences, jealousy and aggression. http:www.//A:/sex differences in mate preferences, jealousy, -and-aggression htm. Date of access 10/12/2007.

Erikson, E. H. (1987). The life cycle completed. New York; Norton.

Gage, J. \& Hancock, D. (2002). Where is the money honey: The socioeconomic effects of mate choice. http://www.freeloadmp3.com. Date of access 10/12/2007.

Glenn, N.D. (2000). Toward a more complete integration of evolutionary and other perspective on age preferences in mates. Behaviour and Brain Sciences, 15(1), 100.

Kalmijn, M. (2001). Assortative meeting and mating: Unintended consequences of organized setting for partner choices. Social Forces, 79(4), 1289-1312.

Koehler, N. (2005). Characteristics and Impression formation in marriage choice. Journal of Social Psychology, 72, 730-738. 
Levi-Strauss, C. (2006). Historical Trends and Variations in educational homogamy. Journal of Marriage and Family, 333, 83 - 95.

Mamasan, M.A. (2005). Female mate preferences: What's love got to do with it? http//www. relationships. blogcity. com/women objectify men.htm. Date of access 10/12/2007.

Newman, B.M. \& Newman P.R. (1995). The development through life: A psychological approach (6 ${ }^{\text {th }}$ Ed.) New Brooks/cole.

Nzidee, K. L (2001). Factors determining choice of marriage partners among student couples of two Universities in Rivers State: Implications for Counselling. Unpublished M.Ed thesis, Nigeria: University of Port Harcourt.

Ogunjuyigbe; P.O. \& Adeyemi, E. O. (2003). Mate selection and marital fertiliy: The case of the Yorubas in the rural areas. Anthropologist, 5 (1), 9-15.

O'Neil, D. (2006). Sex and marriage: Overview. http://anthro.palomor. edu/marriage/marriage/.htm . accessed December 102007.

Orubuloye, I. O. (1987). Some Socio-cultural factors influencing the determinants of fertility: Selected case studies in Nigeria. The Proceedings of the Ife Conference on the Cultural Roots of African fertility Regimes. Ile-Ife, Nigeria and Philadelphia. USA: Department of Demography and Social statistics, Obafemi Awolowo University and population studies centre, University of Pennsylvania, 331- 345.

Todosejvic, B., Ljubinkovic, S. \& Arancic, A. (2003). Mate selection criteria: A trait desirability assessment study of sex differences in Serbia. Evolutionary Psychology, 1, 116-126. 